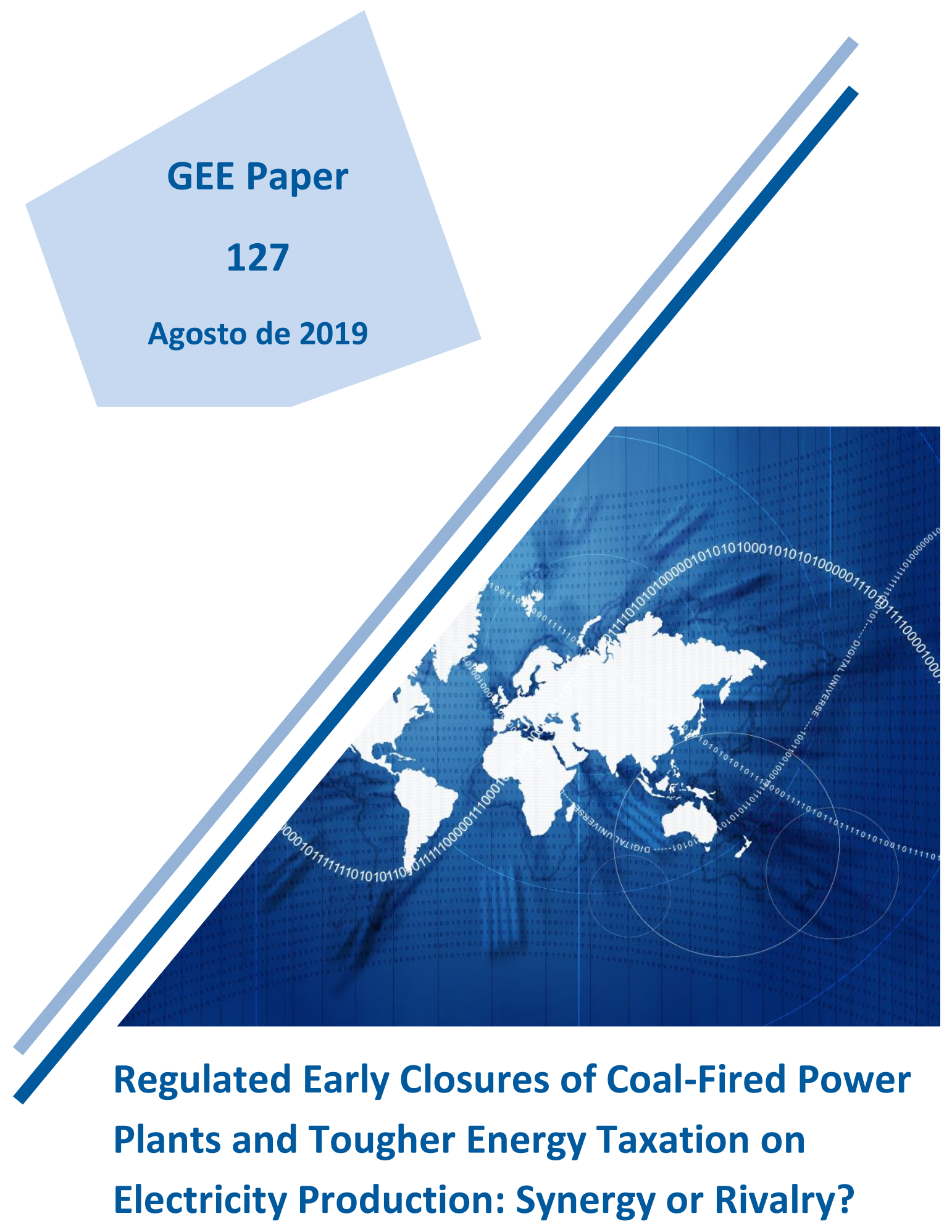

Alfredo Marvão Pereira | Rui Manuel Pereira

Gabinete de Estratégia e Estudos do Ministério da Economia Office for Strategy and Studies of the Ministry of Economy Rua da Prata, n. ㅇ 8 - 1149-057 Lisboa - Portugal 
Gabinete de Estratégia e Estudos 


\section{Regulated Early Closures of Coal-Fired Power Plants and Tougher Energy Taxation on Electricity Production: Synergy or Rivalry? ${ }^{1}$ \\ Alfredo Marvão Pereira ${ }^{2}$, Rui Manuel Pereira ${ }^{3}$}

\section{Abstract}

This article examines the economic, budgetary, distributional and environmental impacts of the interaction between regulated early closure of coal-fired power plants and new energy taxation rules on fossil fuel-operated power plants using a multi-sector and multi-household dynamic general equilibrium model of the Portuguese economy. Simulation results show first that regulated early closures will lead to meaningful reductions in emissions. They will also induce significant detrimental macroeconomic and distributional effects. Second, when the new energy taxation rules are applied to the coal-operated power plants no significant environmental gains or macroeconomic or distributional losses are observed in addition to what already induced by the forced closures. Only the public sector seems to benefit in the form of additional tax revenues. A different situation occurs, however, if the operators of the coal-fired power plants react to the new energy taxes levied on them by unilaterally deciding to decommission their installations. In this case, although the environmental effects will improve, the adverse macroeconomic and distributional effects will substantially deteriorate. Noticeably, the adverse budgetary effects will also be substantially larger. Overall, we find no synergies between the two policies and, actually, the potential for the opposite to be true.

JEL Classification: C68, E62, H23, Q43, Q48

Keywords: Dynamic General Equilibrium, Coal-operated Power Plants, Energy Taxes, Macroeconomic Effects, Distributional Effects, Environmental Effects, Portugal

Note: This article is sole responsibility of the authors and do not necessarily reflect the positions of GEE or the Portuguese Ministry of Economy.

\footnotetext{
${ }^{1}$ The authors want to thank Ana Quelhas, Maria Pedroso Ferreira, and Ana Cristina Nunes for very useful discussions and suggestions. This is the second of two twin papers dealing with the regulated early closures of the two Portuguese coal-fired power plants. The other paper "On the Macroeconomic and Distributional Effects of the Regulated Closure of Coal-Operated Power Plants," [see Pereira and Pereira (2019)], focuses on the detailed effects of the regulated early closure and how they compare with alternative ways of achieving the same environmental effects.

2 Department of Economics, The College of William and Mary, Williamsburg VA 23187

3 Department of Economics, The College of William and Mary, Williamsburg VA 23187
} 


\section{Introduction}

In November 2017, the Portuguese Government announced its commitment to retire all coal-fired power plants by 2030. In addition, in the context of the 2018 State Budget, the tax on energy products (Impostos sobre Produtos Petroliferos e Energéticos, ISP hereafter) was extended to include the taxation of coal used in electricity generation. This extension has a fixed component of 4.26 Euros per ton of coal used and a variable component, which depends on the carbon content of the coal and is indexed to the carbon price in the European Union Emissions Trading System (EU-ETS hereafter).

Portugal has two large coal-fired power plants, one in Sines and the other in Pego. The Sines plant was commissioned in 1985, has a capacity of $1192 \mathrm{MW}$, and is operated by Energias de Portugal (EDP). The Pego plant was commissioned in 1993, it has a capacity of $628 \mathrm{MW}$ and is operated by Tejo Energia, a joint venture between TrustEnergy and Endesa Generation. These two plants play a major role in the Portuguese energy system. Thermal production of electricity from coal accounted for $26 \%$ of the electricity generated in Portugal in 2017: 18\% from Sines, and 8\% from Pego [DGEG (2018)]. These power plants account for more than half of thermal production of electricity in Portugal with natural gas accounting for the remainder. In addition, coal-fired units are a substantial component of electric power operators generating portfolios. In 2017, the production of electricity from coal in Sines accounted for about $12.5 \%$ of the electricity produced by EDP and the production of electricity from coal in Pego accounted for about $42.7 \%$ of the electricity produced by Endesa [EDP (2018)].

The environmental impact of these coal-fired power plants is very substantial. In 2017, Sines and Pego accounted for $19.1 \%$ of carbon dioxide emissions in Portugal. In fact, they were the two largest individual contributors to greenhouse gases emissions in the country [APA (2018)]. Therefore, it is not surprising that increasing efforts of environmental groups and increasing awareness by the policy makers ultimately translated into the regulated early closure of the two power plants by 2030.

In this paper, we consider three research questions. First, want to identify the effects of closing coalfired power plants in 2030 in the absence of any changes in the ISP taxation. Second, we want to determine the effects of the changes in ISP tax rules if the coal-fired power plants close by 2030 as scheduled. Third, we want to establish the effects of the changes in ISP tax rules in an environment in which operators decide to close the plants ahead of the scheduled closure dates as a response to the increases in operation costs implied by the new ISP rules.

We address these questions in the context of a multi-sector, multi-household dynamic computable general equilibrium model of the Portuguese economy that builds upon the aggregate dynamic general equilibrium model, known as DGEP. Previous versions of this model are documented in Pereira and Pereira (2014c), and have been used recently to address energy and climate policy issues [see Pereira and Pereira (2014a, 2014b, 2017a, 2017b, 2017c) and Pereira et al. (2016)]. The current version of the model has a detailed description of the tax system. On the production side, it features a fine differentiation of consumer and producer goods, particularly those with a focus on energy products. On the household side, it captures the heterogeneity in income and consumption patterns by considering five differentiated household groups.

General equilibrium models have been used extensively in energy and environmental studies. For general surveys see Bhattacharyya (1996), Bergman (2005), and Ballard et al. (2009). For a discussion of the merits and concerns with this approach see Sbordone et al. (2010) and Blanchard (2016). In general 
terms, our model follows in the tradition of the early models developed by Borges and Goulder (1984) and Ballard, Fullerton, Shoven and Whalley (2009). In its specifics, however, it is more directly linked to the recent contributions of, for example, Fullerton et al (2012), Goulder and Hafstead (2013), Bhattarai et al. (2016), Tran and Wende (2017), and Annicchiarico et al. (2017).

The remainder of this article proceeds as follows. Section 2 provides a brief description of the disaggregated dynamic general equilibrium model. Section 3 presents the effect of closing the coal fired power plants by 2030. Section 4 discusses the impact of the extension of the tax on energy products to coal used in electricity generation and the effects of accelerated plant closures. Finally, section 5 provides a summary, policy implications, and concluding thoughts.

\section{The Dynamic General Equilibrium Model and Simulation Design}

What follows is necessarily a very brief and general description of the design and implementation of the new multi-sector, multi-household dynamic general equilibrium model of the Portuguese economy. See Pereira and Pereira (2017d) for further details.

\subsection{The General Features}

The dynamic multi-sector general equilibrium model of the Portuguese economy incorporates fully dynamic optimization behavior, detailed household accounts, detailed industry accounts, a comprehensive modeling of the public sector activities, and an elaborate description of the energy sectors. We consider a decentralized economy in a dynamic general equilibrium framework. There are four types of agents in the economy: households, firms, the public sector and a foreign sector. All agents and the economy in general face financial constraints that frame their economic choices. All agents are price takers and are assumed to have perfect foresight. With money absent, the model is framed in real terms.

Households and firms implement optimal choices, as appropriate, to maximize their objective functions. Households maximize their intertemporal utilities subject to an equation of motion for financial wealth, thereby generating optimal consumption, labor supply, and savings behaviors. We consider five household income groups per quintile. While the general structure of household behavior is the same for all household groups, preferences, income, wealth and taxes are household-specific, as are consumption demands, savings, and labor supply.

Firms maximize the net present value of their cash flow, subject to the equation of motion for capital stock to yield optimal output, labor demand, and investment demand behaviors. We consider thirteen production sectors covering the whole spectrum of economic activity in the country. These include energy producing sectors, such as electricity and petroleum refining, other EU-ETS sectors, such as transportation, textiles, wood pulp and paper, chemicals and pharmaceuticals, rubber, plastic and ceramics, and primary metals, as well as sectors not in the EU-ETS, such as agriculture, basic manufacturing and construction. While the general structure of production behavior is the same for all sectors, technologies, capital endowments, and taxes are sector-specific, as are output supply, labor demand, energy demand, and investment demand. The public sector and the foreign sector evolve in a way that is determined by the economic conditions and their respective financial constraints.

All economic agents interact through demand and supply mechanisms in different markets. The general market equilibrium is defined by market clearing in product markets, labor markets, financial 
markets, and the market for investment goods. The equilibrium of the product market reflects the national income accounting identity and the different expenditure allocations of the output by sector of economic activity. The total amount of a commodity supplied to the economy, be it produced domestically, or imported from abroad, must equal the total end-user demand for the product, including the demand by households, by the public sector, its use as an intermediate demand, and its application as an investment good.

The total labor supplied by the different households, adjusted by an unemployment rate that is assumed exogenous and constant, must equal total labor demanded by the different sectors of economic activity. There is only one equilibrium wage rate, although this translates into different household-specific effective wage rates, based on household-specific levels of human capital which obviously differ by quartile of income. Different firms buy shares of the same aggregate labor supply. Implicitly, this means that we do not consider differences in the composition of labor demand among the different sectors of economic activity, in terms of the incorporated human capital levels. Saving by households and the foreign sector equal the value of domestic investment plus the budget deficit.

The evolution of the economy is described by the optimal change in the stock variables - householdspecific financial wealth and sector-specific private capital stock, as well as their respective shadow prices. In addition, the evolution of the stocks of public debt and of the foreign debt act as resource constraints in the overall economy. The endogenous and optimal changes in these stock variables - investment, saving, the budget deficit, and current account deficit - provide the link between subsequent time periods. Accordingly, the model can be conceptualized as a large set of nonlinear difference equations, where flow variables are determined through optimal control rules.

The intertemporal path for the economy is described by the behavioral equations, the equations of motion of the stock and shadow price variables, and the market equilibrium conditions. We define the steady-state growth path as an intertemporal equilibrium trajectory in which all the flow and stock variables grow at the same rate while market prices and shadow prices are constant.

\subsection{Calibration}

The model is calibrated with data for the period 2005-2014 and stock values for 2015 . The calibration of the model is designed to allow the model to replicate as its most fundamental base case, a stylized steady state of the economy, as defined by the trends and information contained in the data set. In the absence of any policy changes, or any other exogenous changes, the model's implementation will just replicate into the future such stylized economic trends. Counterfactual simulations thus allow us to identify marginal effects of any policy or exogenous change, as deviations from the base case.

There are three types of calibration restrictions imposed by the existence of a steady state. First, it determines the value of critical production parameters, such as adjustment costs and depreciation rates, given the initial capital stocks. These stocks, in turn, are determined by assuming that the observed levels of investment of the respective type are such that the ratios of capital to GDP do not change in the steady state. Second, the need for constant public debt and foreign debt to GDP ratios implies that the steadystate budget deficit and the current account deficit are a fraction of the respective stocks of debt equal to the steady-state growth rate. Finally, the exogenous variables, such as public or international transfers, have to grow at the steady-state growth rate. 


\subsection{Numerical Implementation}

The dynamic general equilibrium model is fully described by the behavioral equations and accounting definitions, and thus constitutes a system of nonlinear equations and nonlinear first order difference equations. No objective function is explicitly specified, on account that each of the individual problems (the household, firm and public sector) are set as first order and Hamiltonian conditions. These are implemented and solved using the GAMS (General Algebraic Modeling System) software and the MINOS nonlinear programming solver.

MINOS uses a reduced gradient algorithm generalized by means of a projected Lagrangian approach to solve mathematical programs with nonlinear constraints. The projected Lagrangian approach employs linear approximations for the nonlinear constraints and adds a Lagrangian and penalty term to the objective to compensate for approximation error. This series of sub-problems is then solved using a quasiNewton algorithm to select a search direction and step length.

\section{Reference Case, Counterfactual Scenarios and Simulation Design}

\subsection{Reference Case}

The numerical implementation and calibration of the model is consistent with the economy being in a long-term steady state trajectory. The reference case for our simulations is obtained from this steady state trajectory by incorporating into it international fossil fuel price as projected by the International Energy Agency and carbon dioxide prices as forecasted by the Bloomberg News Energy Finance Group. Our reference case assumes that coal-fired power plants are operational indefinitely, and that the ISP tax rules on such activities in effect in 2017 apply for the time horizon of the model.

\subsection{Counterfactual Scenarios and Simulation Design}

The counterfactual scenarios are designed around two issues: first, the scheduled closure of Sines and Pego in 2030, as announced by the Government on November 2017; and, second, the changes to the ISP tax after 2018 to include coal used in the generation of electricity, which will impact the competitiveness of these power plants in the short term. In CF1, we consider the effects of the regulated early closure of the two coal-operated power plants in the presence of the old ISP tax rules.

There are two sets of additional ISP rules. The first is an energy component, a unit tax which consists of a fixed amount depending directly on the volume of coal used. The second is an additional component, a tax that reflects the carbon content of coal and which is indexed to the price of carbon in the EU-ETS. Specifically, the unit tax rate applying to the purchases of a ton of coal is given by:

$$
\tau_{i s p, f u e l, t}=\tau_{\text {unit }, f u e l, t}+\tau_{\text {carbon }, c, t} \times \varepsilon_{\text {carbon, },}
$$

where, $\varepsilon_{\text {carbon }, c}$ is the conversion factor between physical units of coal and its carbon content.

The effect of the additional tax burden will depend on how long the coal-operated power plants will remain active. At the same time, the increase in fuel costs for electric power facilities associated with the expanded ISP tax is expected to move up the effective closure dates for the two power plants as a result of operational considerations. The policy, as designed, will make the plants unprofitable and lead to their closure years earlier than the date determined by the functional life expectancy of the plant. In this case, 
operators in the electric power industry will react to the additional tax burden with an accelerated closure schedule.

Accordingly, we consider four counterfactual scenarios. We consider first a set of scenarios, CF2 and CF3, in which the extension to the ISP includes only the fixed unit tax on energy, and then a second set of scenarios, CF4 and CF5, in which both the energy and carbon tax components are in place. In CF2 and CF4 there is no reaction by operators in the electric power industry and the plant closure will be as scheduled in 2030. In turn, in CF3 and CF5 the industry responds to the additional tax burden by closing the plants ahead of schedule. Specifically, we consider that the increase in fuel costs associated with the energy component of the tax moves up the plant closure by 5 years (from 2030 to 2025). In addition, the increase in fuel costs driven by both the base fixed energy tax and the carbon content of the fuel are large enough to justify the closure of these plants 10 years earlier than expected based on operational considerations. We present the list of simulation results in Table 1.

\subsection{On the Presentation of the Simulation Results}

We present the simulation results as percent deviations from the reference scenario, thereby allowing for a direct comparison across counterfactual scenarios. In Tables 2 - 5, we focus on the effects of the different policy scenarios as simulated for 2040, which we refer to as long-term effects.

While the coal-operated power plants remain active, the higher costs associated with the production of electricity from coal due to the increase in the ISP tax burden will increase the cost of generating electricity relative to the status quo. Naturally, such price effects disappear in the long term as both power plants eventually close. Accordingly, the main differences among the five scenarios are going to be short-term transitional effects. We would not expect significant differences in the long-run trajectories for the flow variables. The same is not true, naturally, for the stock variables, such as public and foreign deficits or accumulated reduction in emissions.

Accordingly, in most of our discussion of the results we focus in the differences in the transitional effects of the different policies as well as their cumulative effects by 2040. See Tables 6 - 12. Finally, Table 13 presents a snapshot of the main effects of the policies relative to the simple case of the regulated early closure in 2030 , CF1.

\subsection{A Note on Electricity Prices in General Equilibrium}

Lastly, as the price of electricity plays such a critical role in our analysis, and given the different notions prevalent in the literature as to what they represent, it is important to clarify the exact meaning of electricity prices in general equilibrium. In our model, electricity prices are market-clearing prices under general competitive market assumptions.

Electricity prices reflect equilibrium conditions and therefore a balance between supply and demand conditions. Ultimately, they can be conceptualized as average production prices for the amounts of electricity produced under the prevailing market demand conditions.

On the supply side, prices reflect all costs of production: capital, labor, energy, and materials. Because of the dynamic nature of the model, all stocks have fixed costs in the short term but are variable in the long term. On the demand side, prices reflect additional considerations induced by fuel substitution effects by households and businesses as well as higher production costs by businesses across all sectors of 
economic activity. They reflect income effects and losses in purchasing power by households due to higher prices across sectors of economic activity and feedbacks that affect consumers' budget constraints.

4. Simulation Results

4.1 Effects of Regulated Early Closures: CF1

Overall, closures and limits to the coal generating capacity in Portugal result in an increase in electricity prices. The electric power system adjusts to the plant closures by partially replacing coal-operated generation with natural gas. Where possible, further expanding investment in renewable energy, including hydroelectric facilities, wind turbines and solar energy systems will provide for a cost-effective way to address the capacity shortfall associated with discontinuing coal-operated electricity generating units. Finally, an increase in electricity imports partially compensates the decline in domestic electric production.

The closure of the coal-operated power plants has a significant and positive effect on the environmental performance. At the same time, this effect is very narrow in scope, as it comes exclusively, and by design, from the electric power system. These reductions do not reflect an overall change in the patterns of energy use in the economy. This leads to a residual concern on the pedagogical value of this measure of early closure vis-à-vis system wide measures aiming at reducing emissions across the board in the country.

The increase in electricity prices due to the early closure of the coal-operated power plants reverberates throughout the economy, leading to detrimental macroeconomic effects, as well as adverse distributional effects. The negative macroeconomic effects are widespread and notable across sectors of economic activity. The distributional effects are pronounced and highly regressive. These effects also raise concerns with respect to international competitiveness and to social justice.

\subsection{Effects of the ISP Extension - Fixed Energy Component: CF2 and CF3}

It is informative to compare the transitional effects associated with the extension to the ISP tax on energy products under the scheduled 2030 closure date, CF2, and with an accelerated plant closure date, CF3, to our previous counterfactual scenario, CF1, with the same intended 2030 closure date and the old ISP rules.

Under CF2, when closure of the power plants remain as scheduled for 2030, we see a short-run and temporary increase in the price of electricity that ripples throughout the economy. Ultimately, cumulative economic effects by 2040 are only marginally more adverse than in CF1, in terms of GDP, employment, and welfare losses and marginally less adverse in terms of public debt and foreign debt positions. Should the coal-operated power plants remain operational through 2030 we would observe a marginal improvement in the public sector account, reflected in lower levels of public indebtedness, due to the additional tax revenues.

The accelerated plant closure by 2025 induced by the additional operating costs, as in CF3, yields more substantial differences relative to the central counterfactual scenario, CF1. With the earlier closure, we observe an additional cumulative reduction in $\mathrm{CO}_{2}$ emissions of $42.1 \%$. These additional reductions in emissions reflect the additional five years during which the coal-operated power plants will be inactive and not contributing towards atmospheric emissions. 
The accelerated closures also move forward the reduction in economic activity and weaker economic conditions associated with higher electricity costs. The cumulative effect of these additional years of weaker economic conditions is that the cumulative indicators of economic performance deteriorate, accumulated GDP losses increase by $45.4 \%$ and accumulated employment-years increase by $47.5 \%$ visà-vis CF1. Noticeably, the intertemporal welfare indicator are 32.0\% lower than in the central case CF1.

Importantly, in CF3, public debt now deteriorates by $124.5 \%$ relative to the central CF1 case. The larger increase in public debt is due to the combined effect of first, the fact that addition tax revenues from the extension to the tax on energy products applies for a shorter period of time due to the accelerated plant closures and second, that the negative contractionary effects last longer with an accelerated closure schedule.

Overall, if the plant operators do not respond to the new ISP rules, the effects of the new rules will be in general marginal for emissions, macroeconomic performance and welfare and only significant as a new source of public revenues. If, however, the plant operators respond to the new ISP rules by deciding to close down the coal-operated power plants earlier than scheduled, the environmental impact will be much greater but so will be the adverse macroeconomic, budgetary and welfare effects.

\subsection{Effects of the ISP Extension - Energy and Carbon Components: CF4 and CF5}

Finally, we consider the effects of the additional costs associated with both the energy and the carbon tax component of the extension to the ISP tax. In both CF4 and CF5, electric power producers face the additional tax on the energy content as well as the indexed tax on carbon in the cost of coal used in the production of electricity. In the first case, CF4, the scheduled closure of 2030 applies while in the second case, CF5, operators react by anticipating the closure by ten years. In these cases, the patterns of the results are similar to the cases in the previous subsection that considers only the new rules on the energy component of the ISP. The differences in the cumulative environmental, macroeconomic, and distributional effects, however, are substantially more pronounced.

Under the scheduled closures, CF4, the new ISP rules applying to both energy and carbon content have relatively small effects. There is a marginal reduction in emissions, which goes hand in hand with small deteriorations in economic performance and household welfare relative to central counterfactual scenario, CF1. The effects on the public sector account are more favorable with the extension to the tax on energy products only under the assumption that the plants remain operational through 2030 . In this case, we would observe a $9.3 \%$ gain in the public debt position in CF4 with respect to CF1.

The situation is fundamentally different if plant operators accelerate the closure schedule due to operational considerations and the plants cease operation in 2020. It is important to note that these changes are due exclusively to the early closure itself as the extensions to the ISP tax barely becoming effective before seeing the closure of these two facilities. The accumulated gain in $\mathrm{CO}_{2}$ emissions reductions relative to $\mathrm{CF} 1$ increase by $82.2 \%$, which reflects the additional decade without coal-operated power plants.

In turn, the negative effects on economic performance also occur concomitantly for an additional decade. The accumulated detrimental effects on GDP increase by $89.4 \%$ and the accumulated loss in employment-years increases by $95.1 \%$ relative to the central counterfactual scenario in CF1. The intertemporal effects on household welfare increase by $61.3 \%$. The effects on public debt are quite severe under CF5, showing an 310.3\% increase in the public debt in CF5 relative to CF1, as the early closure 
substantially decreases the tax bases as it deepens the contractionary effects and eliminates the tax revenues benefits of the changes to the ISP.

\section{Summary and Policy Implications}

This article examines the environmental, economic, budgetary and distributional effects of the scheduled closure of coal-fired power plants in Portugal as well as the extension of the ISP taxation to coal used in power generation. Specifically, we consider three research questions. First, what are the effects of closing coal-fired power plants in Portugal in 2030 in the absence of any changes in the ISP taxation? Second, what are the effects of the changes in ISP tax rules in an environment in which coal-fired power plants close as scheduled? Third, what are the effects of the changes in ISP tax rules in an environment in which operators decide to close coal-fired power plants ahead of the scheduled closure dates?

The five policy scenarios we consider have similar long-term effects. Over time, once the plants have closed, the extension to the tax on energy products to these facilities has no effect as the new ISP rules disappear when the power plants are effectively closed. The differences in short term transitional effects, however, are very significant, as the new ISP rules are relevant while the plants are operational, and an accelerated closures' schedule extends the duration of the adverse effects on economic performance and household welfare.

More specifically, and in answer to the first research question, we find that the closure of the coaloperated power plants has a significant and positive effect on the environmental performance. The increase in electricity prices due to the early closure of the coal-operated power plants reverberates throughout the economy, leading to detrimental macroeconomic effects, as well as adverse distributional effects. The negative macroeconomic effects are widespread and notable across sectors of economic activity. The distributional effects are pronounced and highly regressive. These effects also raise concerns with respect to international competitiveness and to social justice.

In turn, in response to the second question, the extension of the tax on energy products to coal used in the generation of electricity provides little to no additional environmental gains, as long as private sector agents do not react to the changing profitability of these facilities and maintain the scheduled closure dates at 2030. The economic and distributional effects, however, are marginally worse than the old energy tax rules due to a small increase in production costs, and its effect on electricity prices. Naturally, there is a small gain in the public debt position.

Finally, in terms of the third research question, an important result emerges from the analysis of the effect of the expansion of the tax on energy products to coal used in electricity generation and the potential for their accelerated closure by the operators. Indeed, if operators in the electric power industry react to the new ISP rules by accelerating the closure of the coal operated power plants, the situation changes substantially. The environmental gains are much more pronounced but so too are the negative economic and distributional effects. More importantly from the perspective of the public sector, the public debt position clear deteriorates due to contracting tax bases in the face of weaker economic conditions.

These results lead to several important policy recommendations. First, the regulated early closure of the coal-fired power plants may be very effective in reducing emissions but it is not innocuous from a macroeconomic or a distributional perspective. The domestic authorities, therefore, should undertake the proper efforts to mitigate such adverse effects. 
Second, the new ISP rules are at best irrelevant in the presence of the forced closures. Regardless of whether or not the scheduled closures are enforced, there are no environmental advantages from the new ISP rules although they will certainly produce economic and distributional costs. Emissions reductions would only result from the accelerated closures of the coal generating units, in which case the adverse macroeconomic, distributional, and budgetary effects would be substantially larger. Indeed, the least detrimental of the five policy scenarios we consider, from both macroeconomic and social justice perspectives is the basic central scenario of scheduled closures in 2030 without changes in the ISP.

A final note. In 2016, Portugal introduced a tax on carbon dioxide emissions from fossil fuel combustion activities. This tax was implemented as an additional component to the ISP, based on the carbon content of each type of fossil fuel with a level indexed to the EU-ETS. The tax expanded the scope of policy efforts to reduce emissions beyond the large energy-intensive industrial emitters participating in the EU-ETS which were exempted from this add-on to the ISP - to include the many households and businesses that together can make a substantial contribution towards domestic emissions reductions efforts. The additional component to the ISP for coal based on the carbon content of the fuel effectively doubles the price on carbon in electricity generation from coal and it raises both legal and equity concerns. This is because the coal-fired power plants already participated in the EU-ETS and were therefore already subject to carbon pricing mechanisms. 


\section{References}

1. Agencia Portuguesa do Ambiente, 2018. https://www.apambiente.pt/

2. Annicchiarico, Barbara. Susan Battles, Fabio Di Dio, Pierfrancesco Molina, Pietro Zoppoli. 2017. "GHG mitigation schemes and energy policies: A model-based assessment for the Italian economy." Economic Modelling 61:495-509.

3. Ballard, Charles L. \& Fullerton, Don \& Shoven, John B. \& Whalley, John, 2009. A General Equilibrium Model for Tax Policy Evaluation, National Bureau of Economic Research, University of Chicago Press.

4. Bergman, L. 2005. CGE modeling of environmental policy and resource management. K.G. Mäler, J.R. Vincent (Eds.), Chapter 2 in Handbook of Environmental Economics Vol. 3:1273-1306.

5. Bhattacharyya, Subhes C., 1996. "Applied general equilibrium models for energy studies: a survey," Energy Economics, 18(3):145-164.

6. Bhattarai, K., J. Haughton, D. Tuerck. 2016. "The economic effects of the fair tax: analysis of results of a dynamic CGE model of the US economy," International Economics and Economic Policy 13(3): 451466.

7. Blanchard, Olivier (2016). "Do DSGE Models Have a Future?" Peterson Institute for International Economics, Number PB16-11, 1-4.

8. Borges, A. M. and L. H. Goulder, 1984, "Decomposing the impact of higher energy prices on long-term growth." Chapter 8 in Scarf, H. E. and J. B. Shoven (eds.): Applied General Equilibrium Analysis. Cambridge University Press.

9. Direccao Geral de Energia e Geologia, 2018. https://www.dgeg.gov.pt

10. Dixon, Peter B, and Dale W Jorgenson, ed. 2012. Handbook of Computable General Equilibrium Modeling. North Holland.

11. Energias de Portugal, 2018. https://www.edp.pt/

12. Fullerton, D. \& Garth Heutel \& Gilbert E. Metcalf, 2012. "Does the Indexing of Government Transfers Make Carbon Pricing Progressive?" American Journal of Agricultural Economics 94(2):347-353.

13. Goulder, Lawrence H., and Marc A.C. Hafstead, 2013. "A Numerical General Equilibrium Model for Evaluating U.S. Energy and Environmental Policies." Working Paper, Stanford University, Stanford, CA.

14. Pereira, A., and R. Pereira, 2014a. "Environmental fiscal reform and fiscal consolidation: The quest for the third dividend in Portugal," Public Finance Review 42(2): 222-253.

15. Pereira, A., and R. Pereira, 2014b. "On the environmental, economic and budgetary impacts of fossil fuel prices: A dynamic general equilibrium analysis of the Portuguese case," Energy Economics 42(C): 248-261.

16. Pereira, A., and R. Pereira, 2014c. "DGEP - A dynamic general equilibrium model of the Portuguese economy: Model documentation," The College of William and Mary, Working Paper 127.

17. Pereira, A., and R. Pereira, 2017a. "The economic and budgetary impact of climate policy in Portugal: Carbon taxation in a dynamic general equilibrium model with endogenous public sector behavior," Environmental and Resource Economics 67: 231-259.

18. Pereira, A., and R. Pereira, 2017b. "Achieving the triple dividend in Portugal: A dynamic generalequilibrium evaluation of a carbon tax indexed to emissions trading," Journal of Economic Policy Reform, forthcoming, published online July 2017. 
19. Pereira, A., and R. Pereira, 2017c. "On the relative roles of fossil fuel prices, energy efficiency, and carbon taxation in reducing carbon dioxide emissions," Journal of Environmental Planning and Management 60 (10), pp. 1825-1852.

20. Pereira, A., and R. Pereira, 2017d. The Role of Electricity for the Decarbonization of the Portuguese Economy - DGEP Technical Report, https://mpra.ub.uni-muenchen.de/id/eprint/84782.

21. Pereira, A., and R. Pereira, 2019. "On the Macroeconomic and Distributional Effects of the Regulated Closure of Coal-Operated Power Plants," Working Paper GEE, Ministério da Economia, Lisboa, Portugal.

22. Pereira, A., R. Pereira, and P. Rodrigues, 2016. "A new carbon tax in Portugal: A missed opportunity to achieve the triple dividend?" Energy Policy 93: 110-118.

23. Sbordone, Argia M., Andrea Tambalotti, Krishna Rao, and Kieran Walsh, 2010. Policy Analysis Using DSGE Models: An Introduction. FRBNY Economic Policy Review, 16(2): 23-43.

24. Tran, Chung and Sebastian Wende, 2017. "On the Marginal Excess Burden of Taxation in an Overlapping Generations Model," ANU Working Papers in Economics and Econometrics 2017-652, Australian National University, College of Business and Economics, School of Economics. 
Table 1 List of Simulation Scenarios

\begin{tabular}{|c|c|}
\hline Reference: & $\begin{array}{l}\text { - } \quad \text { No closure for Sines and Pego } \\
\text { - No changes to the ISP rules. }\end{array}$ \\
\hline CF1: & $\begin{array}{l}\text { - Current closure schedule of } 2030 \text { for Sines and Pego } \\
\text { - No changes to the ISP rules. }\end{array}$ \\
\hline CF2: & $\begin{array}{l}\text { - Current closure schedule of } 2030 \text { for Sines and Pego } \\
\text { - New ISP tax rules - fixed amount for energy component alone }\end{array}$ \\
\hline CF3: & $\begin{array}{l}\text { - Modified closure schedule of } 2025 \text { for Sines and Pego } \\
\text { - New ISP tax rules - fixed amount for energy component alone }\end{array}$ \\
\hline CF4 & $\begin{array}{l}\text { - Current closure schedule of } 2030 \text { for Sines and Pego } \\
\text { - New ISP tax rules - fixed amount as well as on carbon content. }\end{array}$ \\
\hline CF5: & $\begin{array}{l}\text { - Modified closure schedule of } 2020 \text { for Sines and } 2021 \text { for Pego } \\
\text { - New ISP tax rules - fixed amount as well as on carbon content. }\end{array}$ \\
\hline
\end{tabular}

Table 2 Long Run Energy and Environmental Effects (2040)

Percent Change from Baseline

\begin{tabular}{|c|c|c|c|c|c|}
\hline & \multirow[b]{2}{*}{$\begin{array}{c}\text { Current } \\
\text { CF1 }\end{array}$} & \multicolumn{2}{|c|}{ Energy Tax } & \multicolumn{2}{|c|}{$\begin{array}{c}\text { Energy and Carbon } \\
\text { Taxes }\end{array}$} \\
\hline & & $\begin{array}{c}\text { Current } \\
\text { CF2 }\end{array}$ & $\begin{array}{c}\text { Early } \\
\text { CF3 }\end{array}$ & $\begin{array}{c}\text { Current } \\
\text { CF4 }\end{array}$ & $\begin{array}{l}\text { Early } \\
\text { CF5 }\end{array}$ \\
\hline Electricity Price & 7.21 & 7.20 & 7.15 & 7.19 & 7.13 \\
\hline Electricity Production & -5.60 & -5.60 & -5.56 & -5.59 & -5.55 \\
\hline Natural gas & 2.12 & 2.12 & 2.10 & 2.11 & 2.09 \\
\hline Renewable energy & 1.50 & 1.51 & 1.61 & 1.53 & 1.65 \\
\hline Net Electricity Imports & 34.55 & 34.53 & 34.28 & 34.49 & 34.16 \\
\hline Energy Demand & -2.08 & -2.08 & -2.07 & -2.08 & -2.07 \\
\hline Electricity Share & -3.58 & -3.58 & -3.57 & -3.58 & -3.56 \\
\hline CO2 Emissions & -22.01 & -22.02 & -22.02 & -22.02 & -22.02 \\
\hline
\end{tabular}


Table 3 Long Run Macroeconomic Effects (2040)

Percent Change from Baseline

\begin{tabular}{l|c|cc|cc}
\hline & & \multicolumn{2}{|c|}{ Energy Tax } & \multicolumn{2}{c}{$\begin{array}{c}\text { Energy and Carbon } \\
\text { Taxes }\end{array}$} \\
& \multirow{2}{*}{$\begin{array}{c}\text { Current } \\
\text { CF1 }\end{array}$} & $\begin{array}{c}\text { Current } \\
\text { CF2 }\end{array}$ & $\begin{array}{c}\text { Early } \\
\text { CF3 }\end{array}$ & $\begin{array}{c}\text { Current } \\
\text { CF4 }\end{array}$ & $\begin{array}{c}\text { Early } \\
\text { CF5 }\end{array}$ \\
\hline GDP & -0.57 & -0.57 & -0.58 & -0.57 & -0.59 \\
Consumption & -0.14 & -0.14 & -0.14 & -0.14 & -0.15 \\
Investment & -0.12 & -0.12 & -0.12 & -0.13 & -0.12 \\
Employment & -0.19 & -0.19 & -0.20 & -0.19 & -0.20 \\
Public Debt & 1.89 & 1.86 & 2.98 & 1.82 & 4.22 \\
Foreign Debt & 0.74 & 0.73 & 1.16 & 0.75 & 1.66 \\
\hline
\end{tabular}

Table 4 Long Run Effects on Industry Output (2040)

Percent Change from Baseline

\begin{tabular}{l|c|cccc}
\hline & & \multicolumn{2}{|c}{ Energy Tax } & \multicolumn{2}{c}{ Energy and Carbon } \\
& Current & Current & Early & Current & Early \\
& CF1 & CF2 & CF3 & CF4 & CF5 \\
\hline Total & -0.572 & -0.571 & -0.582 & -0.569 & -0.591 \\
\hline Petroleum Refining & -0.026 & -0.030 & -0.028 & -0.036 & -0.028 \\
Electricity Production & -5.599 & -5.595 & -5.562 & -5.589 & -5.546 \\
Biomass & 1.281 & 1.286 & 1.349 & 1.297 & 1.380 \\
Agriculture & -0.374 & -0.372 & -0.388 & -0.369 & -0.400 \\
Equipment Manufacturing & -1.435 & -1.432 & -1.527 & -1.427 & -1.594 \\
Construction & -0.132 & -0.133 & -0.132 & -0.134 & -0.130 \\
Transportation & -0.326 & -0.325 & -0.339 & -0.324 & -0.351 \\
Textiles & -0.699 & -0.697 & -0.707 & -0.692 & -0.718 \\
Wood, pulp and paper & -1.499 & -1.493 & -1.541 & -1.482 & -1.575 \\
Chemicals and pharmaceuticals & -0.944 & -0.943 & -0.957 & -0.939 & -0.970 \\
Rubber, plastic and ceramics & -1.226 & -1.224 & -1.256 & -1.221 & -1.279 \\
Primary metals & -1.473 & -1.470 & -1.520 & -1.465 & -1.558 \\
Other & -0.167 & -0.166 & -0.176 & -0.165 & -0.183 \\
\hline
\end{tabular}


Table 5 Long Run Welfare Effects (2040)

\begin{tabular}{c|c|cc|cc} 
& & \multicolumn{3}{c}{ Percent Change from Baseline } \\
\hline & $\begin{array}{c}\text { Current } \\
\text { CF1 }\end{array}$ & $\begin{array}{c}\text { Current } \\
\text { CF2 }\end{array}$ & $\begin{array}{c}\text { Early } \\
\text { CF3 }\end{array}$ & $\begin{array}{c}\text { Current } \\
\text { CF4 }\end{array}$ & $\begin{array}{c}\text { Early } \\
\text { CF5 }\end{array}$ \\
\hline All Households & -0.143 & -0.142 & -0.145 & -0.141 & -0.147 \\
\hline First Quintile (Lowest Income) & -0.317 & -0.316 & -0.319 & -0.315 & -0.321 \\
Second Quintile & -0.198 & -0.198 & -0.199 & -0.197 & -0.200 \\
Third Quintile & -0.146 & -0.146 & -0.147 & -0.145 & -0.148 \\
Fourth Quintile & -0.130 & -0.130 & -0.133 & -0.129 & -0.135 \\
\hline Fifth Quintile (Highest Income) & -0.081 & -0.081 & -0.084 & -0.080 & -0.086 \\
\hline
\end{tabular}

Table 6 Effects on Electricity Prices (Intertemporal)

Percent Change from Baseline

\begin{tabular}{lllllllllllll}
\hline & $\mathbf{2 0 2 0}$ & $\mathbf{2 0 2 1}$ & $\mathbf{2 0 2 2}$ & $\mathbf{2 0 2 3}$ & $\mathbf{2 0 2 4}$ & $\mathbf{2 0 2 5}$ & $\mathbf{2 0 2 6}$ & $\mathbf{2 0 2 7}$ & $\mathbf{2 0 2 8}$ & $\mathbf{2 0 2 9}$ & $\mathbf{2 0 3 0}$ & $\mathbf{2 0 4 0}$ \\
\hline CF1 & -0.11 & -0.13 & -0.15 & -0.18 & -0.21 & -0.24 & -0.27 & -0.31 & -0.35 & -0.39 & 7.12 & 7.21 \\
CF2 & 0.17 & 0.13 & 0.10 & 0.06 & 0.03 & -0.01 & -0.05 & -0.09 & -0.13 & -0.17 & 7.11 & 7.20 \\
CF3 & 0.11 & 0.06 & 0.01 & -0.04 & -0.09 & 6.99 & 6.97 & 6.97 & 6.98 & 6.98 & 6.99 & 7.15 \\
CF4 & 0.77 & 0.71 & 0.65 & 0.60 & 0.55 & 0.50 & 0.45 & 0.40 & 0.36 & 0.32 & 7.10 & 7.19 \\
CF5 & 6.97 & 6.94 & 6.91 & 6.90 & 6.89 & 6.89 & 6.88 & 6.89 & 6.90 & 6.91 & 6.93 & 7.13 \\
\hline
\end{tabular}

Table 7 Cumulative Effects on $\mathrm{CO} 2$ Emissions

\begin{tabular}{ccccccccccccc}
\hline & $\mathbf{2 0 2 0}$ & $\mathbf{2 0 2 1}$ & $\mathbf{2 0 2 2}$ & $\mathbf{2 0 2 3}$ & $\mathbf{2 0 2 4}$ & $\mathbf{2 0 2 5}$ & $\mathbf{2 0 2 6}$ & $\mathbf{2 0 2 7}$ & $\mathbf{2 0 2 8}$ & $\mathbf{2 0 2 9}$ & $\mathbf{2 0 3 0}$ & $\mathbf{2 0 4 0}$ \\
\hline CF1 & -0.01 & -0.02 & -0.02 & -0.03 & -0.03 & -0.04 & -0.05 & -0.06 & -0.08 & -0.09 & -20.32 & - \\
& & & & & & & & - & \\
CF2 & 0.07 & 0.08 & 0.09 & 0.09 & 0.10 & 0.10 & 0.10 & 0.10 & 0.10 & 0.10 & -20.13 & - \\
& & & & & & & & & & & - & 233.38 \\
CF3 & 0.07 & 0.07 & 0.08 & 0.08 & 0.08 & -19.20 & -38.67 & -58.33 & -78.18 & -98.22 & - & - \\
CF4 & 0.26 & 0.30 & 0.33 & 0.37 & 0.40 & 0.43 & 0.45 & 0.48 & 0.50 & 0.53 & -19.71 & - \\
& - & - & - & - & - & - & - & - & - & - & - & - \\
CF5 & 18.12 & 36.64 & 55.36 & 74.26 & 93.36 & 112.64 & 132.11 & 151.78 & 171.63 & 191.68 & 211.92 & 425.22 \\
\hline
\end{tabular}


Table 8 Cumulative Effects on GDP

\begin{tabular}{lllllllllllll}
\hline & $\mathbf{2 0 2 0}$ & $\mathbf{2 0 2 1}$ & $\mathbf{2 0 2 2}$ & $\mathbf{2 0 2 3}$ & $\mathbf{2 0 2 4}$ & $\mathbf{2 0 2 5}$ & $\mathbf{2 0 2 6}$ & $\mathbf{2 0 2 7}$ & $\mathbf{2 0 2 8}$ & $\mathbf{2 0 2 9}$ & $\mathbf{2 0 3 0}$ & $\mathbf{2 0 4 0}$ \\
\hline CF1 & 0.01 & 0.02 & 0.03 & 0.04 & 0.05 & 0.07 & 0.08 & 0.10 & 0.12 & 0.14 & -0.41 & -6.41 \\
CF2 & 0.00 & 0.00 & 0.01 & 0.02 & 0.02 & 0.03 & 0.04 & 0.06 & 0.07 & 0.09 & -0.45 & -6.44 \\
CF3 & 0.01 & 0.01 & 0.02 & 0.04 & 0.05 & -0.46 & -0.99 & -1.52 & -2.06 & -2.62 & -3.18 & -9.32 \\
CF4 & -0.02 & -0.03 & -0.04 & -0.05 & -0.06 & -0.06 & -0.06 & -0.06 & -0.06 & -0.05 & -0.60 & -6.56 \\
CF5 & -0.50 & -1.01 & -1.52 & -2.04 & -2.56 & -3.10 & -3.64 & -4.18 & -4.74 & -5.31 & -5.88 & - \\
\hline
\end{tabular}

Table 9 Cumulative Effects on Employment

\begin{tabular}{lllllllllllll}
\hline & $\mathbf{2 0 2 0}$ & $\mathbf{2 0 2 1}$ & $\mathbf{2 0 2 2}$ & $\mathbf{2 0 2 3}$ & $\mathbf{2 0 2 4}$ & $\mathbf{2 0 2 5}$ & $\mathbf{2 0 2 6}$ & $\mathbf{2 0 2 7}$ & $\mathbf{2 0 2 8}$ & $\mathbf{2 0 2 9}$ & $\mathbf{2 0 3 0}$ & $\mathbf{2 0 4 0}$ \\
\hline CF1 & 0.04 & 0.05 & 0.05 & 0.06 & 0.07 & 0.08 & 0.10 & 0.11 & 0.12 & 0.14 & -0.05 & -2.11 \\
CF2 & 0.03 & 0.04 & 0.05 & 0.06 & 0.07 & 0.08 & 0.09 & 0.10 & 0.12 & 0.13 & -0.05 & -2.11 \\
CF3 & 0.05 & 0.07 & 0.08 & 0.09 & 0.11 & -0.07 & -0.24 & -0.42 & -0.61 & -0.79 & -0.99 & -3.12 \\
CF4 & 0.02 & 0.02 & 0.03 & 0.03 & 0.04 & 0.05 & 0.06 & 0.07 & 0.08 & 0.10 & -0.08 & -2.14 \\
CF5 & -0.11 & -0.28 & -0.45 & -0.62 & -0.80 & -0.98 & -1.17 & -1.35 & -1.54 & -1.74 & -1.94 & -4.12 \\
\hline
\end{tabular}

Table 10 Cumulative Effects on Public Debt

\begin{tabular}{lllllllllllll}
\hline & $\mathbf{2 0 2 0}$ & $\mathbf{2 0 2 1}$ & $\mathbf{2 0 2 2}$ & $\mathbf{2 0 2 3}$ & $\mathbf{2 0 2 4}$ & $\mathbf{2 0 2 5}$ & $\mathbf{2 0 2 6}$ & $\mathbf{2 0 2 7}$ & $\mathbf{2 0 2 8}$ & $\mathbf{2 0 2 9}$ & $\mathbf{2 0 3 0}$ & $\mathbf{2 0 4 0}$ \\
\hline CF1 & $\mathbf{0 . 0 0}$ & $\mathbf{0 . 0 0}$ & -0.01 & -0.01 & -0.02 & -0.02 & -0.03 & -0.04 & -0.06 & -0.07 & -0.09 & 6.99 \\
CF2 & -0.01 & -0.01 & -0.02 & -0.03 & -0.05 & -0.06 & -0.08 & -0.11 & -0.13 & -0.16 & -0.20 & 6.68 \\
CF3 & -0.01 & -0.01 & -0.03 & -0.04 & -0.06 & -0.08 & 0.02 & 0.22 & 0.55 & 1.01 & 1.59 & 15.69 \\
CF4 & -0.01 & -0.02 & -0.04 & -0.06 & -0.08 & -0.10 & -0.14 & -0.17 & -0.21 & -0.26 & -0.31 & 6.34 \\
CF5 & -0.01 & 0.09 & 0.30 & 0.63 & 1.08 & 1.65 & 2.36 & 3.20 & 4.17 & 5.29 & 6.56 & 28.68 \\
\hline
\end{tabular}


Table 11 Cumulative Effects on Foreign Debt

\begin{tabular}{lllllllllllll}
\hline & & & & & & & \multicolumn{4}{c}{$2015=100$} \\
\hline CF1 & 0.01 & 0.02 & 0.03 & 0.05 & 0.07 & 0.09 & 0.12 & 0.15 & 0.18 & 0.22 & 0.26 & 6.44 \\
CF2 & 0.01 & 0.02 & 0.03 & 0.05 & 0.07 & 0.09 & 0.12 & 0.15 & 0.19 & 0.23 & 0.27 & 6.40 \\
CF3 & 0.01 & 0.03 & 0.05 & 0.07 & 0.10 & 0.13 & 0.25 & 0.45 & 0.75 & 1.14 & 1.63 & 13.44 \\
CF4 & 0.02 & 0.04 & 0.06 & 0.10 & 0.13 & 0.17 & 0.22 & 0.27 & 0.33 & 0.40 & 0.47 & 6.84 \\
CF5 & 0.03 & 0.14 & 0.33 & 0.61 & 0.99 & 1.46 & 2.04 & 2.72 & 3.52 & 4.43 & 5.47 & 24.04 \\
\hline
\end{tabular}

Table 12 Cumulative Effects on Welfare

\begin{tabular}{lllllllllllll}
\hline & $\mathbf{2 0 2 0}$ & $\mathbf{2 0 2 1}$ & $\mathbf{2 0 2 2}$ & $\mathbf{2 0 2 3}$ & $\mathbf{2 0 2 4}$ & $\mathbf{2 0 2 5}$ & $\mathbf{2 0 2 6}$ & $\mathbf{2 0 2 7}$ & $\mathbf{2 0 2 8}$ & $\mathbf{2 0 2 9}$ & $\mathbf{2 0 3 0}$ & $\mathbf{2 0 4 0}$ \\
\hline CF1 & -0.03 & -0.03 & -0.04 & -0.04 & -0.04 & -0.04 & -0.04 & -0.04 & -0.04 & -0.04 & -0.18 & -1.75 \\
CF2 & -0.04 & -0.05 & -0.05 & -0.06 & -0.06 & -0.06 & -0.07 & -0.07 & -0.07 & -0.07 & -0.21 & -1.77 \\
CF3 & -0.06 & -0.07 & -0.07 & -0.08 & -0.08 & -0.22 & -0.36 & -0.50 & -0.64 & -0.79 & -0.93 & -2.52 \\
CF4 & -0.07 & -0.08 & -0.09 & -0.10 & -0.11 & -0.12 & -0.12 & -0.13 & -0.14 & -0.14 & -0.28 & -1.83 \\
CF5 & -0.22 & -0.35 & -0.49 & -0.63 & -0.76 & -0.91 & -1.05 & -1.19 & -1.34 & -1.49 & -1.64 & -3.26 \\
\hline
\end{tabular}

Table 13 Comparative Results: Cumulative Effects by 2040

\begin{tabular}{|c|c|c|c|c|c|}
\hline & \multirow[b]{2}{*}{$\begin{array}{l}\text { Current } \\
\text { CF1 }\end{array}$} & \multicolumn{2}{|c|}{ Energy Tax } & \multicolumn{2}{|c|}{$\begin{array}{c}\text { Energy and Carbon } \\
\text { Taxes }\end{array}$} \\
\hline & & $\begin{array}{l}\text { Current } \\
\text { CF2 }\end{array}$ & $\begin{array}{l}\text { Early } \\
\text { CF3 }\end{array}$ & $\begin{array}{l}\text { Current } \\
\text { CF4 }\end{array}$ & $\begin{array}{l}\text { Early } \\
\text { CF5 }\end{array}$ \\
\hline $\mathrm{CO} 2$ & 100.0 & 100.0 & 142.0 & 99.8 & 182.0 \\
\hline GDP & 100.0 & 100.5 & 145.4 & 103.9 & 189.4 \\
\hline Employment & 100.0 & 100.0 & 147.9 & 101.4 & 195.3 \\
\hline Public Debt & 100.0 & 95.6 & 224.5 & 90.7 & 410.3 \\
\hline Foreign Debt & 100.0 & 99.4 & 208.7 & 106.2 & 373.3 \\
\hline Welfare Loss & 100.0 & 101.1 & 144.0 & 104.5 & 186.5 \\
\hline
\end{tabular}




\section{GEE Papers}

1: Evolução do Comércio Externo Português de Exportação (1995-2004)

João Ferreira do Amara

2: Nowcasting an Economic Aggregate with Disaggregate Dynamic Factors: An Application to Portuguese GDP Antonio Morgado | Luis Nunes | Susana Salvado

3: Are the Dynamics of Knowledge-Based Industries Any Different? Ricardo Mamede | Daniel Mota | Manuel Godinho

4: Competitiveness and convergence in Portugal Jorge Braga de Macedo

5: Produtividade, Competitividade e Quotas de Exportação Jorge Santos

6: Export Diversification and Technological Improvement: Recent Trends in the Portuguese Economy Manuel Cabra

7: Election Results and Opportunistic Policies: An Integrated Approach

Toke Aidt | Francisco Veiga | Linda Veiga

8: Behavioural Determinants of Foreign Direct Investment Ricardo Pinheiro-Alves

9: Structural Transformation and the role of Foreign Direct Investment in Portugal: a descriptive analysis for the period 1990-2005

Miguel de Freitas | Ricardo Mamede

10: Productive experience and specialization opportunities for Portugal: an empirical assessment

Miguel de Freitas | Susana Salvado | Luis Nunes | Rui Costa Neves

11: The Portuguese Active Labour Market Policy during the period 1998-2003 - A Comprehensive Conditional Difference-In-Differences Application Alcina Nunes | Paulino Teixeira

12: Fiscal Policy in a Monetary Union: Gains from Changing Institutions

Susana Salvado

13: Coordination and Stabilization Gains of Fiscal Policy in a Monetary Union Susana Salvado

14: The Relevance of Productive Experience in the Process of Economic Growth: an Empirical Study Diana Vieira

15: Employment and Exchange rates: the Role of Openness and Technology

Fernando Alexandre | Pedro Bação | João Cerejeira Miguel Portela

16: Aggregate and sector-specific exchange rate indexes for the Portuguese economy

Fernando Alexandre | Pedro Bação | João Cerejeira | Miguel Portela
17: The Macroeconomic Determinants of Cross Border Mergers and Acquisitions and Greenfield Investments Paula Neto | Antonio Brandao | António Cerqueira

18: Does the location of manufacturing determine service sectors' location choices? Evidence from Portugal Nuno Crespo | Maria Paula Fontoura

19: A hipótese do Investment Development Path: Uma Abordagem por Dados em Painel. Os casos de Portugal e Espanha

Miguel Fonseca | António Mendonça | José Passos

20: Outward FDI Effects on the Portuguese Trade Balance, 1996-2007

Miguel Fonseca | António Mendonça | José Passos

21: Sectoral and regional impacts of the European Carbon Market in Portugal

Margarita Robaina Alves | Miguel Rodriguez | Catarina Roseta-Palma

22: Business Demography Dynamics in Portugal: A NonParametric Survival Analysis

Alcina Nunes | Elsa Sarmento

23: Business Demography Dynamics in Portugal: A Semiparametric Survival Analysis Alcina Nunes | Elsa Sarmento

24: Digging Out the PPP Hypothesis: an Integrated Empirical Coverage Miguel de Carvalho | Paulo Júlio

25: Regulação de Mercados por Licenciamento Patrícia Cerqueira | Ricardo Pinheiro Alves

26: Which Portuguese Manufacturing Firms Learn by Exporting?

Armando Silva | Óscar Afonso | Ana Paula Africano

27: Building Bridges: Heterogeneous Jurisdictions, Endogenous Spillovers, and the Benefits of Decentralization Paulo Júlio | Susana Peralta

28: Análise comparativa de sobrevivência empresarial: o caso da região Norte de Portugal Elsa Sarmento | Alcina Nunes

29: Business creation in Portugal: Comparison between the World Bank data and Quadros de Pessoal Elsa Sarmento | Alcina Nunes

30: The Ease of Doing Business Index as a tool for Investment location decisions João Zambujal Oliveira | Ricardo Pinheiro Alves

31: The Politics of Growth: Can Lobbying Raise Growth and Welfare?

Paulo Júlio

32: The choice of transport technology in the presence of exports and FDI

José Pedro Ponte | Armando Garcia Pires

33: Tax Competition in an Expanding European Union Ronald Davies | Johannes Voget 
34: The usefulness of State trade missions for the internationalization of firms: an econometric analysis Ana Paula Africano | Aurora Teixeira | André Caiado

35: The role of subsidies for exports: Evidence from Portuguese manufacturing firms Armando Silva

36: Criação de empresas em Portugal e Espanha: análise comparativa com base nos dados do Banco Mundial Elsa Sarmento | Alcina Nunes

37: Economic performance and international trade engagement: the case of Portuguese manufacturing firms Armando Silva | Oscar Afonso | Ana Paula Africano

38: The importance of Intermediaries organizations in international R\&D cooperation: an empirical multivariate study across Europe Aurora Teixeira | Margarida Catarino

39: Financial constraints, exports and monetary integration Financial constraints and exports: An analysis of Portuguese firms during the European monetary integration

Filipe Silva | Carlos Carreira

40: FDI and institutional reform in Portugal Paulo Júlio | Ricardo Pinheiro-Alves | José Tavares

41: Evaluating the forecast quality of GDP components Paulo Júlio | Pedro Esperança | João C. Fonseca

42: Assessing the Endogeneity of OCA conditions in EMU Carlos Vieira | Isabel Vieira

43: Labor Adjustment Dynamics: An Application of System GMM

Pedro Esperança

44: Corporate taxes and the location of FDI in Europe using firm-level data Tomás Silva | Sergio Lagoa

45: Public Debt Stabilization: Redistributive Delays versus Preemptive Anticipations Paulo Júlio

46: Organizational Characteristics and Performance of Export Promotion Agencies: Portugal and Ireland compared Inês Ferreira | Aurora Teixeira

47: Evaluating the forecast quality of GDP components: An application to $\mathrm{G} 7$ Paulo Júlio | Pedro Esperança

48: The influence of Doing Business' institutional variables in Foreign Direct Investment Andreia Oliva

49: Regional and Sectoral Foreign Direct Investment in Portugal since Joining the EU: A Dynamic Portrait Irina Melo | Alexandra Lopes

50: Institutions and Firm Formation: an Empirical Analysis of Portuguese Municipalities Simão Arouca

51: Youth Unemployment in Southern Europe João Leão | Guida Nogueira
52: Financiamento da Economia Portuguesa: um Obstáculo ao Crescimento?

João Leão | Ana Martins | João Gonçalves

53: O Acordo de Parceria Transatlântica entre a UE e os EUA constitui uma ameaça ou uma oportunidade para a Economia Portuguesa? João Leão | Guida Nogueira

54: Prescription Patterns of Pharmaceuticals Ana Gonçalves

55: Economic Growth and the High Skilled: the Role of Scale Eects and of Barriers to Entry into the High Tech Pedro Gil | Oscar Afonso | Paulo Brito

56: Finanças Públicas Portuguesas Sustentáveis no Estado Novo (1933-1974)? Ricardo Ferraz

57: What Determines Firm-level Export Capacity? Evidence from Portuguese firms

Ana Gouveia I Ana Luisa Correia

58: The effect of developing countries' competition on regional labour markets in Portugal Tiago Pereira

59: Fiscal Multipliers in the 21st century Pedro Brinca | Hans Holter | Per Krusell | Laurence Malafry

60: Reallocation of Resources between Tradable and NonTradable Sectors in Portugal: Developing a new Identification Strategy for the Tradable Sector Ana Fontoura Gouveia | Filipa Canas

61: Is the ECB unconventional monetary policy effective? Inês Pereira

62: The Determinants of TFP Growth in the Portuguese Manufacturing Sector Daniel Gonçalves | Ana Martins

63: Practical contribution for the assessment and monitoring of product market competition in the Portuguese Economy - estimation of price cost margins Luis Folque

64: The impact of structural reforms of the judicial system: a survey

Ana Gouveia | Silvia Santos | Corinna Herber

65: The short-term impact of structural reforms on productivity growth: beyond direct effects Ana Gouveia | Silvia Santos | Inês Gonçalves

66: Assessing the Competitiveness of the Portuguese Footwear Sector Fábio Batista | José Matos | Miguel Matos

67: The empirics of agglomeration economies: the link with productivity Ana Gouveia | Silvia Santos | Marli Fernandes

68: Determinants of the Portuguese GDP stagnation during the 2001-2014 period: an empirical investigation Carlos Figueira

69: Short-run effects of product markets' deregulation: a more productive, more efficient and more resilient economy? Ana Gouveia | Silvia Santos | Gustavo Monteiro 
70: Portugal: a Paradox in Productivity Ricardo Pinheiro Alves

71: Infrastructure Investment, Labor Productivity, and International Competitiveness: The Case of Portugal Alfredo Pereira | Rui Pereira

72: Boom, Slump, Sudden stops, Recovery, and Policy Options. Portugal and the Euro Olivier Blanchard | Pedro Portugal

73: Case Study: DBRS Sovereign Rating of Portugal. Analysis of Rating Methodology and Rating Decisions Annika Luisa Hofmann | Miguel Ferreira | João Lampreia

74: For Whom the Bell Tolls: Road Safety Effects of Tolls on Uncongested SCUT Highways in Portugal Alfredo Pereira | Rui Pereira | João Pereira dos Santos

75: Is All Infrastructure Investment Created Equal? The Case of Portugal

Alfredo Pereira | Rui Pereira

76: Why Virtuous Supply-Side Effects and Irrelevant Keynesian Effects are not Foregone Conclusions: What we Learn from an Industry-Level Analysis of Infrastructure Investments in Portugal

Alfredo Pereira | Rui Pereira

77: The Role of Gravity Models in Estimating the Economic Impact of Brexit

Graham Gudgin | Ken Coutts | Neil Gibson | Jordan Buchanan

78: Infrastructure Investment in Portugal and the Traded/NonTraded Industry Mix

Alfredo Pereira | Rui Pereira

79: Goods and Factor Market Integration: A Quantitative Assessment of the EU Enlargement

Lorenzo Caliendo | Fernando Parro | Luca David Opromolla | Alessandro Sforza

80: Understanding productivity dynamics:a task taxonomy approach

Tiago Fonseca | Francisco Lima | Sonia C. Pereira

81: On the Effects of Infrastructure Investments on Industrial $\mathrm{CO} 2$ Emissions in Portugal

Alfredo Pereira | Rui Pereira

82: Assessing Competition With the Panzar-Rosse Model: An empirical analysis of European Union banking industry Suzana Cristina Silva Andrade

83: Health Care Investments and Economic Performance in Portugal: An Industry Level Analysis Alfredo Pereira | Rui Pereira | Pedro G. Rodrigues

84: Is deregulation of product and labour markets promoting employment and productivity? A difference-indifferences approach

Hugo Correia | Ana Fontoura Gouveia

85: Foreign acquisition and internal organization Paulo Bastos | Natália P. Monteiro | Odd Rune Straume

86: Learning, Prices, and Firm Dynamics Paulo Bastos | Daniel A. Dias | Olga A. Timoshenko

87: The Diffusion of Knowledge via Managers' Mobility Giordano Mion | Luca David Opromolla|Alessandro Sforza
88: Empresas Zombie em Portugal - Os sectores não transacionáveis da Construção e dos Serviços Gabriel Osório de Barros | Filipe Bento Caires | Dora Xarepe Pereira

89: Collective bargaining through the magnifying glass: A comparison between the Netherlands and Portugal Alexander Hijzen | Pedro Martins | Jante Parlevliet

90: A Lower VAT Rate on Electricity in Portugal: Towards a Cleaner Environment, Better Economic Performance, and Less Inequality Alfredo Pereira | Rui Manuel Pereira

91: Who Seeks Re-Election: Local Fiscal Restraints and Political Selection

Susana Peralta | João Pereira dos Santos

92: Assessing the Competitiveness of the Metalworking Sector João Marinho | Pedro Carvalho

93: The efficiency of Portuguese Technology Transfer Offices and the importance of university characteristics Aurora Teixeira | André Monteiro

94: Persistence in innovation and innovative behavior in unstable environments Joana Costa | Anabela Botelho | Aurora Teixeira

95: The effect of entrepreneurial origin on firms' performance - The case of Portuguese academic spinoffs Natália Barbosa | Ana Paula Faria

96: Absorptive Capacity and Firms' Generation of Innovation Revisiting Zahra and George's Model Dina Pereira | João Leitão

97: Innovations in digital government as business facilitators: implications for Portugal João Martins | Linda Veiga

98: Innovation and the economic downturn: Insights from Portuguese firms

Hugo Pinto | Tiago Santos Pereira | Elvira Uyarra

99: European Funds and Firm Dynamics: Estimating Spillovers from Increased Access João Pereira dos Santos | José Tavares

100: Corporate Leverage and Investment in Portugal Ana Martins | José Henrique Gonçalves | João Mário Ferreira Duque

101: The effects of official and unofficial information on tax compliance

Filomena Garcia | Luca David Opromolla | Andrea Vezzulli | Rafael Marques

102: Competition effect on innovation and productivity - The Portuguese case

Anabela Santos | Michele Cincera | Paulo Neto | Maria Manuel Serrano

103: Measuring the Welfare of Intermediation in Vertical Markets

Javier D. Donna | Pedro Pereira | Tiago Pires | Andre Trindade

104: Of course Collusion Should be Prosecuted. But Maybe... Or (The case for international antitrust agreements) Filomena Garcia | Jose Manuel Paz y Minõ | Gustavo Torrens 
105: Product market competition and gender discrimination Dudley Cooke | Ana P. Fernandes | Priscila Ferreira

106: Integration of Small Technology-Based Firms in Aeronautics

Anabela Reis | Joana Mendonça | Ligia Urbina

107: The Effects of Highway Tolls on Private Business Activity Results from a Natural Experiment

João Pereira dos Santos | David B. Audretsch | Dirk Dohse

108: Competition and Firm Productivity: Evidence from Portugal

Pedro Carvalho

109: Do Exchange Traded Funds (ETFs) Outperform the Market? Evidence from the Portuguese Stock Index Carlos Manuel Pinheiro | Hugo Hilário Varela

110: Assessing the Competitiveness of the Portuguese Chemical Sector

Ana Rita Marques | Cátia Silva

111: A General Equilibrium Theory of Occupational Choice under Optimistic Beliefs about Entrepreneurial Ability Michele Dell'Era | Luca David Opromolla | Luis SantosPinto

112: O Mercado Segurador em Portugal: O Papel dos Gestores na Constituição de Provisões

Soraia de Sousa Bornett | Carlos Manuel Pinheiro

113: Exploring the implications of di erent loan-to-value macroprudential policy designs

Rita Basto | Sandra Gomes | Diana Lima

114: The Determinants of TFP Growth in the Portuguese Service Sector

Ana Martins | Tiago Domingues | Catarina Branco

115: Agglomeration and Industry Spillover Effects in the Aftermath of a Credit Shock José Jorge | Joana Rocha

116: Entrepreneurial Human Capital and Firm Dynamics Francisco Queiró

117: Global Value Chains and Vertical Specialization: The case of Portuguese Textiles and Shoes exports

Tiago Domingues
118: Firm heterogeneity and exports in Portugal: Identifying export potential

Frederico Oliveira Torres

119: Vantagens Comparativas Reveladas e suas determinantes: Uma Aplicação à Economia Portuguesa

Guida Nogueira | António Portugal Duarte

120: A Look at the main channels of Potential Impact of Brexit on the Portuguese Economy

Guida Nogueira | Paulo Inácio

121: How internationalization and competitiveness contribute to get public support to innovation? The Portuguese case

Anabela Santos, Michele Cincera, Paulo Neto and Maria Manuel Serrano

122: Grande Guerra e Guerra Colonial: Quanto Custaram aos Cofres Portugueses?

Ricardo Ferraz

123: Financing a Renewable Energy Feed-in Tariff with a Tax on Carbon Dioxide Emissions: A Dynamic Multi-Sector General Equilibrium Analysis for Portugal Rui M. Pereira | Alfredo M. Pereira

124: Brown Sugar, how come you taste so good? The impact of a soda tax on prices and consumption Judite Gonçalves | João Pereira dos Santos

125: ARFIMA Reference Forecasts for Worldwide CO2 Emissions and the National Dimension of the Policy Efforts to Meet IPCC Targets José Beirute | Alfredo M. Pereira

126: Reference Forecasts for CO2 Emissions from Fossil-Fuel Combustion and Cement Production in Portugal José M. Belbute | Alfredo M. Pereira

127: Regulated Early Closures of Coal-Fired Power Plants and Tougher Energy Taxation on Electricity Production: Synergy or Rivalry?

Alfredo Marvão Pereira | Rui Manuel Pereira 


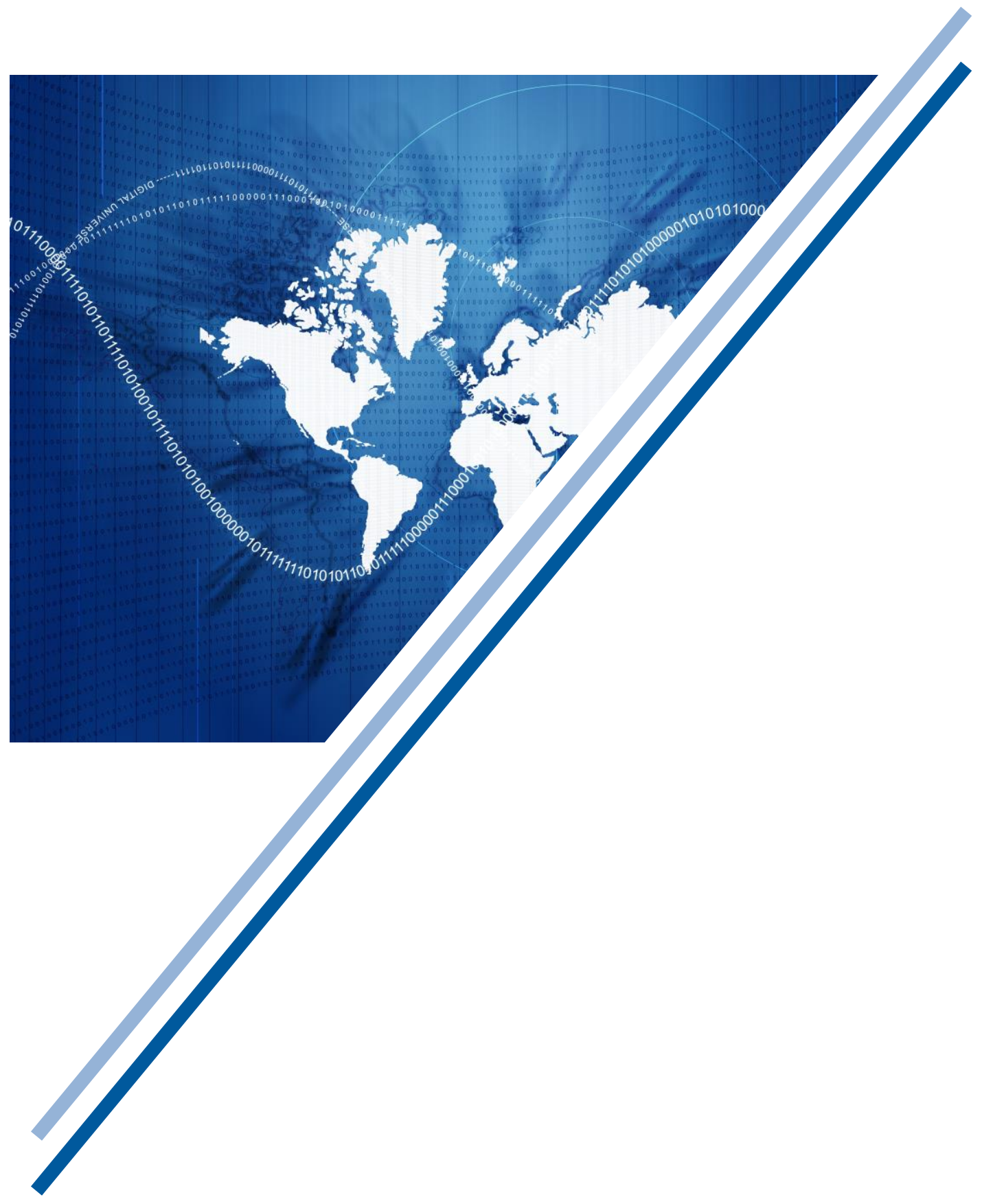

